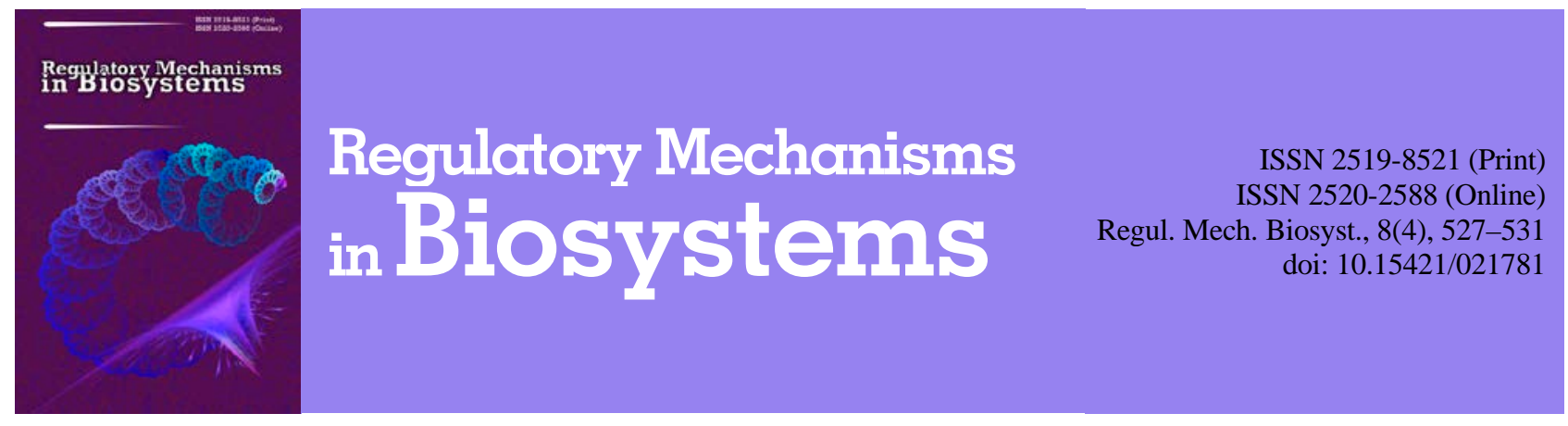

\title{
Adhesive properties of film-forming strains of staphylococci, isolated from different compartments of the human gastrointestinal tract
}

\author{
T. M. Shevchenko, O. Y. Hovorukha, Y. S. Voronkova, O. S. Voronkova \\ Oles Honchar Dnipro National University, Dnipro, Ukraine
}

Article info

Received 20.10.2017

Received in revised form 14.11.2017

Accepted 16.11.2017

Oles Honchar Dnipro National University,

Gagarin Ave., 72,

Dnipro, 49010, Ukraine.

Tel.: +38-056-372-58-76

E-mail:

dnushevchenkot@gmail.com

\begin{abstract}
Shevchenko, T. M., Hovorukha, O. Y., Voronkova, Y. S., \& Voronkova, O. S. (2017). Adhesive properties of filmforming strains of staphylococci, isolated from different compartments of the human gastrointestinal tract. Regulatory Mechanisms in Biosystems, 8(4), 527-531. doi:10.15421/021781
\end{abstract}

Dysbiotic disorders, realized as changes in the composition of microbiota of different biotopes, are among the most difficult conditions to cure. This is due primarily to the fact that opportunistic microorganisms that actually mediate the development of such states are characterized by an increased colonization potential, which at the first stage of penetration into a biotope is realized as adhesion to the cell surface. When a microorganism successfully realises this stage it enters into a competitive relationship with the autochthonous flora and begins to inhibit its development. Such strategy becomes especially successful if the colonist has the ability to form a biofilm. It is known that the initial stage of biofilm formation is adhesion onto the surface, therefore, the study of adhesive properties of clinical strains opens the way for understanding the initial processes of development of dysbiosis and allows for the development of preventive measures. The aim of our research was to investigate the differences in the manifestation of adhesive properties of film-forming strains of staphylococci isolated from different compartments of the human gastrointestinal tract. We established that the frequency of detection of film-forming strains of staphylococci in different compartments of the gastrointestinal tract in the norm or during the development of lesions was for Staphylococcus aureus from $23.8 \%$ to $79.4 \%$, and for S. epidermidis from $15.4 \%$ to $100 \%$, which indicates the significant role of these microorganisms in the development of complications at the specified biotope. It was determined that the maximal manifestation of adhesive properties was typical for biofilm-forming strains of $S$. epidermidis and $S$. aureus isolated during intestinal dysbiosis. The average values of the adhesion index were $6.00 \pm 1.41$ and $5.88 \pm 2.22$ and the index of adhesion of microorganisms was $6.61 \pm 1.46$ and $6.64 \pm 2.48$ respectively. The lowest value of these indices for film-forming strains was determined for strains of staphylococci isolated from the gastrointestinal tracts of patients suffering from food poisoning $-2.60 \pm 1.14$ and $2.86 \pm 1.23$ respectively. The obtained data suggest that the ability for biofilm-formation and a high level of adhesion indexes indicate with a high probability that a strain will cause long-lasting lesions, such as dysbiosis. The determination of these markers at the diagnostic stage will allow a broader study of the biological properties of the strain, which may be the basis for the development of an individual, optimal therapeutic scheme that conforms with the tasks of personalized medicine.

Keywords: Staphylococcus; adhesive properties; biofilm; gastrointestinal tract; dysbiosis

\section{Адгезивні властивості плівкотвірних штамів стафілококів, виділених із різних відділів шлунково-кишкового тракту людини}

\author{
Т. М. Шевченко, О. Ю. Говоруха, Ю. С. Воронкова, О. С. Воронкова
}

Дніпровський національний університет імені Олеся Гончара, Дніпро, Украӥна

\footnotetext{
Дисбіотичні порушення, що виражаються у змінах складу мікробіоти окремих біотопів, - одні $з$ найбільш складно виліковних станів. Умовно-патогенні мікроорганзми, які власне опосередковують розвиток таких станів, відрізняються підвищеним колонізаційним потенціалом, що на першому етапі їх проникнення реалізується як адгезія до клітинної поверхні. За вдалої реалізації цього етапу мікроорганізм вступає у конкурентні відносини з автохтонною флорою та починає інгібувати іï розвиток. Особливого успіху така стратегія досягає за наявності в колоніста здатності до формування біоплівки. Частота виявлення плівкотвірних штамів стафілококів у різних відділах шлунково-кишкового тракту в умовах норми та за розвитку уражень становила для S. aureus $23,8-79,4 \%$, а для S. epidermidis - 15,4-100,0\%. Максимальний прояв адгезивних властивостей типовий для біоплівкотвірних штамів епідермального та золотистого стафілококів, виділених за дисбіозу кишечника. Середні значення показника адгезії становили 6,0 і 5,9, а індексу адгезивності мікроорганізмів 6,6 і 6,7, відповідно. Найменші вказані показники для плівкотвірних штамів визначено для штамів стафілококів, виділених під час харчових отруєнь: 2,6 та 2,9, відповідно.
}

Ключові слова: стафілококи; адгезивні властивості; біоплівка; шлунково-кишковий тракт; дисбіоз 


\section{Вступ}

Поширення стафілококових біоплівок нині доволі відома проблема біології та медицини. У першу чергу це пов'язано 3 тим, що у плівковій формі мікроорганізми набувають ознак посиленої стійкості до дії факторів довкілля (Hoiby et al., 2010; McKew et al., 2011; Wright et al., 2013). Крім того, плівкотвірні штами мають підвищений колонізаційний потенціал, що дозволяє їм швидко адаптуватися до практично будь-якого біотопу з витриманням конкурентного впливу автохтонних мікроорганізмів (Sannasiddappa et al., 2011). Колонізаційна здатність визначається низкою зовнішніх і внутрішніх факторів, серед яких першочергове значення звичайно мають властивості самих мікроорганізмів. Переважне значення серед різних біологічних властивостей штамів мікроорганізмів для колонізації різних біотопів організму людини мають адгезивні властивості, адже адгезія - перший процес, який власне визначає можливість колонізації поверхні та закріплення на ній (Paster et al., 2001; Nair et al., 2014; Lin et al., 2015). Посилені адгезивні властивості сприяють затриманню транзиторних мікроорганізмів і підвищенню їх виживання в умовах антагоністичних відносин та дії захисних факторів місцевого імунітету слизових оболонок (Patterson et al., 2010; Becker et al., 2014). Стафілококи у більшості мають виражені адгезивні властивості, саме тому їх розглядають як найбільш схильні до плівкотвірних процесів бактерії (Becker et al., 2014; Misawa et al., 2015). За потенціалом до утворення біоплівки вони поступаються лише псевдомонадам (Hou et al., 2012; Orazi and O’Toole, 2017). Під час первинного прикріплення до поверхні відбувається активація специфічних груп генів, що забезпечують посилений синтез екзополімеру та молекул, які здійснюють міжклітинні контакти, зокрема, триває синтез міжклітинного полісахаридного адгезину. Ці групи генів активуються лише у прикріплених форм і їх нокаут унеможливлює утворення біоплівки (Giaouris et al., 2015; Hobley et al., 2015). У разі реалізації вказаних подій ініціюється формування біоплівки (Archer et al., 2011; Gostev and Sidorenko, 2012; Wright et al., 2013).

Мета цієї статті - оцінити відмінності прояву адгезивних властивостей плівкотвірних штамів стафілококів, виділених із різних відділів шлунково-кишкового тракту людини.

\section{Матеріал і методи досліджень}

Для досліджень взято штами стафілококів, виділені з різних відділів шлунково-кишкового тракту людини: ротової порожнини (відбирання тампоном 3 ясенних карманів) та 3 кишечника (фекаліi). Окремо досліджували групи штамів, виділені від осіб із порушеннями мікробіоти та від осіб, яких вважали здоровими.

Культури ідентифікували за результатами вивчення морфологічних, тинкторіальних та фізіолого-біохімічних ознак. Ідентифікацію отриманих штамів проводили відповідно до ознак, наведених у визначнику бактерій Берджі (Holt et al., 1994). Для виділення представників роду Staphylococcus проводили висівання на стафілококовий агар 110 (HiMedia, Індія) та інкубували протягом доби за температури $37^{\circ} \mathrm{C}$. Мікроскопіювали матеріал зі зрослих колоній мікроорганізмів (Labinskaia and Volina, 2008). Зі зрослих колоній кремових і жовтих відтінків відбирали матеріал, 3 якого виготовляли мікроскопічні препарати, які забарвлювали за Грамом. Визначаючи грампозитивні коки, зібрані у грона, культури тестували за такими ознаками: ферментація глюкози в анаеробних умовах $з$ утворенням кислоти (позитивна), каталаза (позитивна), ріст за концентрації натрію хлориду 15\% (позитивний). Варіабельні ознаки: відновлення нітратів до нітритів, наявність коагулази та продукція гемолізинів.

Здатність до плівкоутворення визначали на 96-лункових планшетах (Медполимер, РФ). Для цього добову культуру суспендували в ізотонічному розчині $\mathrm{NaCl}(0,5 \%)$ за стандартом мутності $1 \cdot 10^{4} \mathrm{KУО/мл.} \mathrm{Отриману} \mathrm{суспензію} \mathrm{у} \mathrm{кількості} 50$ мкл вносили у лунки планшета, що містили 150-200 мкл поживного бульйону
(HiMedia, Індія). Інкубацію проводили у термостаті за температури $37{ }^{\circ} \mathrm{C} 72$ години. Після закінчення інкубації залишки живильного середовища обережно відбирали шприцом, а лунки промивали тричі ізотонічним розчином $(0,5 \% \mathrm{NaCl})$. Якщо на стінках та дні лунок планшета залишалася біоплівка, штам вважали біоплівкотвірним (Lyamin et al., 2012; Tchebotar and Guryev, 2012).

Адгезивну активність досліджених штамів стафілококів визначали за їх здатністю адсорбуватися на букальному епітелії (Brilis et al., 1986; Kovalenko et al., 2010). Для цього штами вирощували протягом 24 год. у поживному бульйоні, після чого центрифугували 5 хв. за 6000 об./хв. Одержану клітинну масу ресуспендували у фосфатно-сольовому буфері такого складу (г/100 мл): $\mathrm{NaCl}-0,85, \mathrm{Na}_{2} \mathrm{HPO}_{4}-1,42$ (pH 7,2). Одержували суспензію бактерій, яка містила $1,0 \cdot 10^{9}$ клітин/мл. Зразок букального епітелію переносили у буфер, епітеліоцити центрифугували за 6000 об./хв супернатант видаляли, а одержаний осад знову ресуспендували у буфері та центрифугували в такому саме режимі. Кількість клітин підраховували у камері Горясва. Готували суспензію епітеліальних клітин у концентрації $1,0 \cdot 10^{8}$ клітин/мл. Одержані суспензії бактеріальних та епітеліальних клітин змішували у рівних об’ємах у мікропробірці та інкубували за температури $37^{\circ} \mathrm{C}$ протягом 30 хв. Після закінчення експозиції клітини двічі промивали фосфатно-сольовим буфером протягом 5 хв за 6000 об./хв щоб звільнити епітеліоцити від неприкріплених бактеріальних клітин. 3 осаду клітин готували мазки, забарвлювали за Грамом і підраховували кількість бактерій, які знаходилися на поверхні епітеліоцитів (Kovalenko et al., 2010).

Адгезію оцінювали за індексом адгезивності мікроорганізмів (ІАМ) за формулою:

$$
\mathrm{IAM}=\frac{C \Pi A}{K У E} \cdot 100 \%,
$$

де IAM - індекс адгезивності мікроорганізмів (середня кількість мікробних клітин, адгезованих на одному еритроциті, що бере участь в адгезивному процесі); СПА - середній показник адгезії (середня кількість мікроорганізмів, що прикріпились до одного еритроцита, під час підрахунку не менше 50 еритроцитів); КУЕ - коефіцієнт участі еритроцитів (відсоток еритроцитів, що мають на поверхні адгезовані мікроорганізми).

Під час оцінювання критеріїв адгезії згідно з методикою при значенні IAM < 1,75 мікроорганізми вважали неадгезивними; від 1,76 до 2,50 - низькоадгезивними; від 2,51 до 4,00 - середньоадгезивними та за IAM $>4,00$ - високоадгезивними.

\section{Результати та їх обговорення}

Біологічні властивості штамів стафілококів, виділених із ротової порожнини здорових осіб і осіб із пародонтитом. Із ротової порожнини здорових осіб виділено 14 штамів стафілококів, а від осіб із пародонтитом - 51 штам, які ідентитфіковано як S. aureus - 1 та 27 штамів, відповідно та S. epidermidis 13 та 24 штами, відповідно. Для всіх них вивчено здатність до утворення біоплівки. 3 ізолятів золотистих стафілококів, виділених в осіб із пародонтитом, здатністю до плівкоутворення володіли 8 (29,6\%). Єдиний ізолят золотистого стафілокока, виділений від здорової особи, не проявляв здатності до утворення біоплівки.

Серед ізолятів епідермального стафілокока відсоток здатних до плівкоутворення більший: із виділених від осіб із пародонтитом 19 (79,2\%) ізолятів плівкотвірні, натомість серед ізолятів епідермального стафілокока, виділених від здорових осіб, частка плівкотвірних штамів менша - 2 (15,4\%). Це може свідчити на користь того, що плівкоутворення - додатковий чинник, який ускладнює патологічний процес.

Для всіх штамів стафілококів, виділених із ротової порожнини здорових осіб та від осіб із пародонтитом, досліджено прояв адгезивних властивостей (рис. 1, 2).

Єдиний штам золотистого стафілокока, виділений у здорової особи, був неадгезивним, а решта тією чи іншою мірою мали здат- 
ність до адгезіі. Рівень адгезивних властивостей плівкотвірних штамів був значно вищим, ніж у неплівкотвірних. Зокрема, для штамів золотистого стафілокока, виділених в осіб із пародонтитом i здатних до утворення біоплівки, СПА склав 5,25 $\pm 1,98$, а IAM 5,99 \pm 2,32 за відповідних показників неплівкотвірних штамів $1,63 \pm 1,42$ та $1,82 \pm 1,58$.

Більшість плівкотвірних штамів - 7 (87,5\%) - належали до високоадгезивних і лише 1 (12,5\%) - до середньоадгезивних. Серед неплівкотвірних штамів лише 2 (10,5\%) належали до високоадгезивних, інші - до середньо- (2, 10,5\%), низько- (12, $63,2 \%)$ або неадгезивних узагалі (3, 15,8\%).

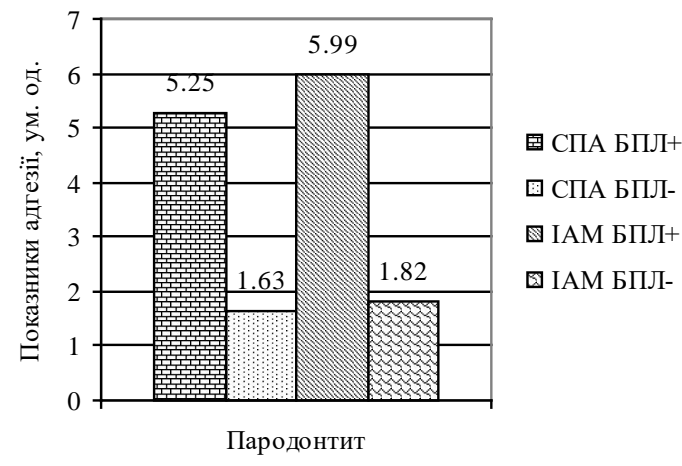

Рис. 1. СПА та IAM штамів $S$. aureus, виділених

зі здорової ротової порожнини та з пародонтитом:

БПЛ+ - плівкотвірні штами, БПЛ- - неплівкотвірні штами

Штами епідермального стафілокока, не здатні до утворення біоплівки, мали близькі показники адгезивності. Так, СПА та IAM штамів, виділених у здорових осіб, становили відповідно 1,73 \pm 1,49 та 1,96 $\pm 1,64$, а виділені від осіб із пародонтитом - 2,00 $\pm 1,58$ та 2,26 $\pm 1,76$, що вказує на підвищений рівень агресивності виділених в осіб із пародонтитом штамів. Вищі показники мали штами, здатні до утворення біоплівки: СПА та IAM виділених від здорових осіб штамів становили 3,50 \pm 0,71 та 3,99 \pm 1,03, а $з$ пародонтитом - відповідно 4,53 \pm 2,46 та 5,13 \pm 2,79.

Отримані дані про мікроорганізми у зубній бляшці відповідають існуючим відомостям про склад бактерій у біоплівці, типовій для порожнини рота (Nishihara and Koseki, 2004; Paster et al., 2011; Tsarev et al., 2011).

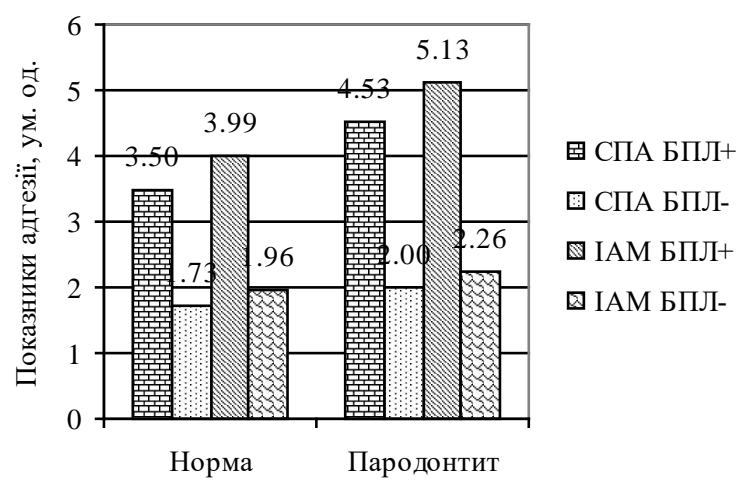

Рис. 2. СПА та IAM штамів S. epidermidis, виділених

зі здорової ротової порожнини та з пародонтитом:

БПЛ+ - плівкотвірні штами, БПЛ- - неплівкотвірні штами

Біологічні властивості штамів стафілококів, виділених за дисбіозу кишечника. Стафілококи - один із найвідоміших бактеріальних збудників уражень шлунково-кишкового тракту, зокрема дисбіозів. Перебування у нижніх відділах шлунково-кишкового тракту потребує від мікроорганізму наявності виражених колонізаційних властивостей для формування пристінкової флори та реалізації конкурентних взаємодій із нормальними симбіонтами. У цьому сенсі стафілококи відрізняються значною колонізаційною ефективністю: вони здатні продукувати низку факторів, що сприяють виживанню у середовищі кишечника (Labinskaia and
Volina, 2008), їх колонізаційний потенціал може підвищуватися за рахунок адгезії та здатності формувати біоплівку (Moormeier et al., 2014). Для всіх узятих у подальше дослідження 38 штамів стафілококів проводили визначення здатності до утворення біоплівки та адгезивних властивостей. Дослідження здатності до утворення біоплівки показало, що всі чотири штами епідермального стафілокока - плівкотвірні, а зі штамів золотистого (n = 34) - 27 (79,4\%). Значення СПА та ІАМ плівкотвірних штамів золотистого та епідермального стафілококів сягали 5,88 \pm 2,22 і 6,64 \pm 2,48 та $6,00 \pm 1,41$ та $6,61 \pm 1,46$, відповідно, за аналогічних показників неплівкотвірних штамів $1,43 \pm 0,98$ та 1,60 $\pm 1,11$ (рис. 3).

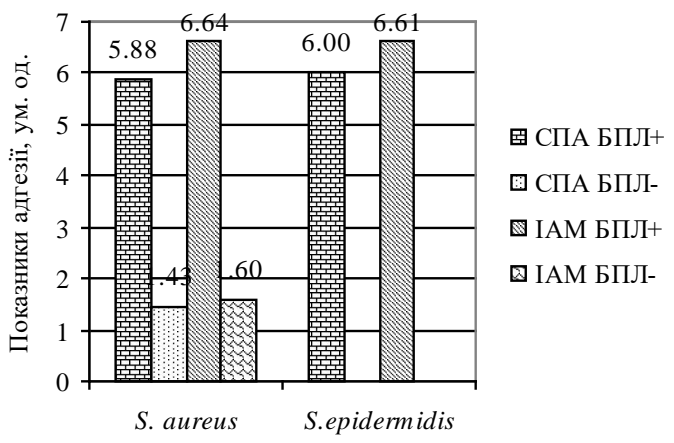

Рис. 3. СПА та IАМ штамів стафілококів, виділених із біологічного матеріалу від осіб із дисбіозом шлунковокишкового тракту: БПЛ+ - плівкотвірні штами, БПЛ- - неплівкотвірні штами

Адгезивні властивості виділених штамів варіювали, але серед штамів, здатних до формування біоплівки, переважно були високоадгезивні - $25(92,6 \%)$ штамів золотистого та всі 4 епідермального стафілококів. Серед неплівкотвірних високі адгезивні властивості проявив лише 1 (14,3\%) штам.

Властивості стафілококів, виділених в осіб із харчовими отрусннями. Стафілококи займають значне місце у структурі харчових отруєнь, зумовлюючи важкі випадки за рахунок продукування токсинів (Labinskaia and Volina, 2008). Здатністю до утворення біоплівки володіли лише 5 штамів $(23,8 \%)$ з 21 .

Дослідження адгезивних властивостей дозволило встановити, що білышість штамів, виділених в осіб із харчовими отруєннями, належали до середньо- або низькоадгезивних. Із плівкотвірних 4 штами (80,0\%) були середньоадгезивними, а 1 (20,0\%) - низькоадгезивним. Серед неплівкотвірних середньоадгезивними були $8(50,0 \%)$, низькоадгезивними - 5 (31,3\%), неадгезивними 2 (12,5\%). Високоадгезивним виявився лише один штам (6,3\%).

Плівкотвірні штами мали дещо вищі показники СПА та IAM

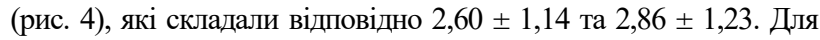

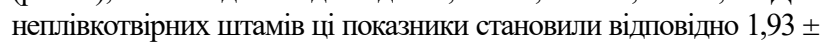
1,39 та 2,22 $\pm 1,60$. Це дозволяє стверджувати, що штами, які викликають гострі ураження, мають нижчий колонізаційний потенціал порівняно з тими, що персистують в організмі хронічно.

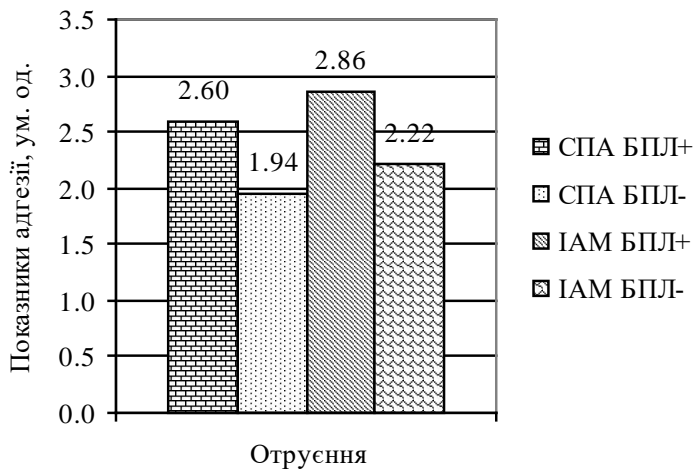

Рис. 4. СПА та IАМ штамів $S$. aureus, виділених iз біологічного матеріалу від осіб із харчовими отруєннями: БПЛ+ - плівкотвірні штами, БПЛ- - неплівкотвірні штами 
Для плівкотвірних штамів, виділених від осіб без ознак патологічного процесу, показники адгезії нижчі, як і для штамів, виділених за гострої форми ураження - харчового отруєння. Для штамів епідермального стафілокока, виділених із ротової порожнини здорових осіб, у середньому СПА становив 3,50, а IАM - 3,99, що відповідає рівню середньоадгезивних штамів. Неадгезивних штамів серед плівкотвірних взагалі не було, а переважали високоадгезивні (понад 75-80\%). Ponomarenko et al. (2014) вказують, що адгезивними властивостями володіють практично всі штами стафілококів, виділені за патологічних станів у людини, але рівень їх адгезивних властивостей у понад $60 \%$ випадків оцінюється як середній. Частка високоадгезивних штамів складає третину або чверть від усіх плівкотвірних, що нижче за показники, отримані нами. Ці самі автори вказують, що серед штамів, виділених від назальних носіїв із числа медперсоналу (умовно-здорові особи), також переважали середньоадгезивні форми. Це збігається з отриманими нами даними про те, що від здорових осіб (зокрема, з їх ротової порожнини) виділялися середньоадгезивні штами.

Загалом, адгезивні властивості - важливий аспект вивчення біоплівкотвірних штамів мікроорганізмів, адже саме здатність до адгезії на поверхнях лежить в основі формування плівок (Naumenko and Shipitsyna, 2011). Адгезивні властивості можна розглядати як фактор конкуренції умовно-патогенних мікрорганізмів із представниками нормальної мікробіоти, оскільки вдале закріплення у біотопі дозволяє досягти певного популяційного рівня (Buharin, 2009). Прояв адгезивних властивостей залежить здебільшого від бактерії, а також може контролюватися макроорганізмом (Akinkunmi et al., 2014). 3 боку останнього - це реакція специфічних і неспецифічних механізмів місцевого імунітету, наприклад, секреторних антитіл, лізоциму тощо, а також за рахунок наявності на поверхні клітин структур, здатних взаємодіяти з адгезинами, наприклад, такого білка як фібронектин, що викликає формування плівки (Murashkin et al., 2012).

\section{Висновки}

Частота виявлення плівкотвірних штамів стафілококів у різних відділах шлунково-кишкового тракту за норми та за патологічних змін становила для S. aureus 23,8-79,4\%, а для S. epidermidis - 15,4-100,0\%. Максимальний прояв адгезивних властивостей типовий для штамів епідермального та золотистого стафілококів, виділених за дисбіозу кишечника. Середні значення СПА становили 6,00 \pm 1,41 і 5,88 $\pm 2,22, \mathrm{IAM}-6,61 \pm$ 1,46 і 6,64 $\pm 2,48$, відповідно. Найменше значення вказаних показників для плівкотвірних штамів визначено для штамів стафілококів, виділених в осіб із харчовими отруєннями: 2,60 \pm 1,14 та 2,86 $\pm 1,23$, відповідно.

\section{References}

Akinkunmi, E. O., Adeyemi, O. I., Igbeneghu, O. A., Olaniyan, E. O., Omonisi, A. E., \& Lamikanra, A. (2014). The pathogenicity of Staphylococcus epidermidis on the intestinal organs of rats and mice: An experimental investigation. BMC Gastroenterology, 14, 126.

Archer, N. K., Mazaitis, M. J., Costerton, J. W., Leid, J. G., Powers, M. E., \& Shirtliff, M. E. (2011). Staphylococcus aureus biofilms: Properties, regulation, and roles in human disease. Virulence, 2(5), 445-459.

Becker, K., Heilmann, C., \& Peters, G. (2014). Coagulase-negative Staphylococci. Clinical Microbiology Reviews, 27(4), 870-926.

Brilis, V. I., Brilene, T. A., Lentsner, H. P., \& Lentsner, A. A. (1986). Metodika izucheniya adgezivnogo protsessa mikroorganizmov [Method for studying the adhesive process of microorganisms]. Laboratomoe Delo, 4, 210-212 (in Russian).

Buharin, O. V. (2009). Infektsiya - modelnaya sistema assotsiativnogo simbioza [Infection is a model system of associative symbiosis]. Journal of Microbiology, Epidemiology and Immunobiology, 1, 83-86 (in Russian).

Giaouris, E., Heir, E., Desvaux, M., Hebraud, M., Meretre, T., Langsrud, S., Doulgeraki, A., Nychas, G.-J., Kacaniova, M., Czaczyk, K., Olmez, H., \& Simoes, M. (2015). Intra- and inter-species interactions within biofilms of important foodbome bacterial pathogens. Frontiers in Microbiology, 6, 841.
Gostev, V. V., \& Sidorenko, S. V. (2012). Bakterialnyie bioplenki i infektsii [Bacterial biofilms and infections]. Journal of Infectology, 2(3), 4-15 (in Russian).

Hobley, L., Harkins, C., MacPhee, C. E., \& Stanley-Wall, N. R. (2015). Giving structure to the biofilm matrix: An overview of individual strategies and emerging common themes. FEMS Microbiology Reviews, 39(5), 649-669.

Hoiby, N., Bjarnsholt, T., Givskov, M., Molin, S., \& Ciofu, O. (2010). Antibiotic resistance of bacterial biofilms. International Journal of Antimicrobial Agents, 35, 322-332.

Holt, J. G., Krieg, N. R., Sneath, P. H. A., Staley, J. T., \& Williams, S. T. (Eds.). (1994). Bergey's manual of determinative bacteriology. Williams \& Wilkins, Baltimore.

Hou, W., Sun, X., Wang, Z., \& Zhang, Y. (2012). Biofilm-forming capacity of Staphylococcus epidermidis, Staphylococcus aureus, and Pseudomonas aeruginosa from ocular infections. Investigative Ophthalmology and Visual Science, 53(9), 5624-5631.

Kovalenko, N. K., Livinska, O. P., Poltavska, O. A., Garmasheva, I. L., Shinkarenko, L. M., \& Oleshchenko, L. T. (2010). Probiotychni vlastyvosti promyslovykh shtamiv laktobatsyl i bifidobakteriy [Probiotic properties of industrial strains of lactobacilli and bifidobacteria]. Microbiologichny Zhurnal, 72(1), 9-17 (in Ukrainian).

Labinskaia, A. S., \& Volina, Y. H. (Eds.). (2008). Rukovodstvo po medicinskoi mikrobiolohii. Obshaia i sanitarnaia mikrobiolohiia [Manual of medical microbiology. General and sanitary microbiology]. Binom, Moscow (in Russian).

Lin, M. H., Shu, J. C., Lin, L. P., Chong, K. Y., Cheng, Y. W., Du, J. F., \& Liu, S. T. (2015). Elucidating the crucial role of poly N-acetylglucosamine from Staphylococcus aureus in cellular adhesion and pathogenesis. PLoS One, 10(4), e0124216.

Lyamin, A. V., Botkin, E. A., \& Zhestkov, A. V. (2012). Metodyi vyiyavleniya bioplenok v meditsine: Vozmozhnosti i perspektivyi [Methods of biofilm evaluation: Opportunities and perspectives]. Clinical Microbiology and Antimicrobial Chemotherapy, 14(1), 17-22 (in Russian).

McKew, B. A., Taylor, J. D., McGenity, T. J., \& Underwood, G. J. (2011). Resistance and resilience of benthic biofilm communities from a temperate saltmarsh to desiccation and rewetting. The ISME Journal, 5, 30-41.

Misawa, Y., Kelley, K. A., Wang, X., Wang, L., Park, W. B., Birtel, J., Saslowsky, D., \& Lee, J. C. (2015). Staphylococcus aureus colonization of the mouse gastrointestinal tract is modulated by wall teichoic acid, capsule, and surface proteins. PLOS Pathogens, 11(7), e1005061.

Moormeier, D. E., Bose, J. L., Horswill, A. R., \& Bayles, K. W. (2014). Temporal and stochastic control of Staphylococcus aureus biofilm development. mBio, 5(5), e01341-14.

Murashkin, N., Gluzmin, M., Skoblikow, N., Bakulev, A., Materikin, A., Gluzmina, M., \& Khotko, A. (2012). Rol metitsillinrezistentnyih shtammov zolotistogo stafilokokka $\mathrm{v}$ patogeneze tyazhelyih form atopicheskogo dermatita $\mathrm{v}$ detskom vozraste. Puti dostizheniya remissii [Role of MRSA strains in the pathogenesis of severe atopic dermatitis in childhood. Ways of achieving remission]. Vestnik Dermatologii i Venerologii, 1, 66-74 (in Russian).

Nair, N., Biswas, R., Gotz, F., \& Biswas, L. (2014). Impact of Staphylococcus aureus on pathogenesis in polymicrobial infections. Infection and Immunity, 82(6), 2162-2169.

Naumenko, Z. S., \& Shipitsyna, I. V. (2011). Sravnitelnaya otsenka adgezivnoy aktivnosti bakteriy, vyidelennyih u bolnyih iz osteomieliticheskogo ochaga i iz ran otkryityih perelomov [Comparative evaluation of adhesive activity of the bacterii, isolated in patients from their osteomyelitic focus, as well as from open fracture wounds]. Orthopaedic Genius, 4, 31-34 (in Russian).

Nishihara, T., \& Koseki, T. (2004). Microbial etiology of periodontitis. Periodontology, 36, 14-26.

Orazi, G., \& O’Toole, G. A. (2017). Pseudomonas aeruginosa alters Staphylococcus aureus sensitivity to vancomycin in a biofilm model of cystic fibrosis infection. mBio, 8(4), e00873-17.

Paharik, A. E., \& Horswill, A. R. (2016). The staphylococcal biofilm: Adhesins, regulation, and host response. Microbiology Spectrum, 4(2).

Paster, B. J., Boches, S. K., Galvin, J. L., Ericson, R. E., Lau, C. N., Levanos, V. A., Sahasrabudhe, A., \& Dewhirst, F. E. (2001). Bacterial diversity in human subgingival plaque. Journal of Bacteriology, 183(12), 3770-3783.

Patterson, J. L., Stull-Lane, A., Girerd, P. H., \& Jefferson, K. K. (2010). Analysis of adherence, biofilm formation and cytotoxicity suggests a greater virulence potential of Gardnerella vaginalis relative to other bacterial-vaginosis-associated anaerobes. Microbiology, 156, 392-399.

Ponomarenko, S. V., Voronkina, I. A., Osolodchenko, T. P., Port, O. V., \& Pirtskhalava, T. V. (2014). Zdatnist do bioplivkoutvorennya izolyativ S. aureus, vydilenykh z riznykh ekonish [The ability to biofilm formation isolates S. aureus, received by different ecological niches]. Bulletin of Problems Biology and Medicine, 112, 245-248 (in Ukrainian).

Sannasiddappa, T. H., Costabile, A., Gibson, G. R., \& Clarke, S. R. (2011). The influence of Staphylococcus aureus on gut microbial ecology in an in vitro continuous culture human colonic model system. PLoS One, 6(8), e23227. 
Tchebotar, I. V., \& Guryev, E. L. (2012). Laboratornaya diagnostika klinicheski znachimyih bioplyonochnyih protsessov [Laboratory diagnostics of clinically significant microbial biofilms]. Voprosyi Diagnostiki v Pediatrii, 4, 15-20 (in Russian).

Tsarev, V., Trefilov, A., Kleymenova, G., \& Levkin, A. (2011). Prostranstvennovremennaya model formirovaniya bioplyonki polosti rta: Vzaimosvyaz pro- tsessov pervichnoy adgezii i mikrobnoy kolonizatsii [The space-time mode of oral biofilm formation: The interrelation of primary adhesion and microbial colonization]. Sovremennaya Stomatologiya, 2, 22-27 (in Russian).

Wright, C. J., Burns, L. H., Jack, A. A., Back, C. R., Dutton, L. C., Nobbs, A. H. Lamont, R. J., \& Jenkinson, H. F. (2013). Microbial interactions in building of communities. Molecular Oral Microbiology, 28(2), 83-101. 